How to cite : Tumey, M. R., Kumaat J. C., Oroh H., V. (2020). Identifikasi Sampah Plastik di Sepanjang Pesisir Madidir Kota Bitung. Jurnal Episentrum, 1(3), 13-18. doi: 10.36412/jepst.v1i3.2355

Copyright (O) 2020 Martha R. Tumey. All Right Reserved

\title{
IDENTIFIKASI SAMPAH PLASTIK DI SEPANJANG PESISIR MADIDIR KOTA BITUNG
}

\author{
Martha R. Tumey ${ }^{1}$, Joyce. Ch. Kumaat ${ }^{2}$, Hilda V. Oroh ${ }^{3}$ \\ ${ }^{1}$ Mahasiswa Program Studi Geografi, Fakultas Ilmu Sosial, Universitas Negeri Manado \\ ${ }^{2,3}$ Program Studi Geografi, Fakultas Ilmu Sosial, Universitas Negeri Manado \\ e-mail: marthatumey7@gmail.com
}

\begin{abstract}
The purpose of this study was to determine the distribution of plastic waste along the coast of Madidir, Bitung City. This type of research is descriptive quantitative using a survey approach that analyzes data spatially. The method of collecting waste is carried out in 2 ways, namely: the first way, the installation of points at 4 locations, namely at Madidir Weru, Madidir Uure, Madidir Unet, and Madidir Main which follow the coastline of Madidir. The second way, when point installation takes place in 4 locations where calculations, measurements and weights are also carried out directly on the coast of Madidir. Based on the research results, the plastic waste obtained starts from mineral drink bottles, straws, aqua glasses, etc. At 4 location points, it is known that the amount of plastic waste in madidir weru is 221 per piece, madidir unet is 172 per fruit, madidir madidir is 141 per piece, and madidir ure is 71 per piece. While the total amount of plastic waste along the coast of Madidir City of Bitung is 605 per piece. The results of the identification of the distribution of plastic waste along the Madidir coast of Bitung City can be seen as contributing to marine pollution.
\end{abstract}

Keywords: Distribution, Plastic Waste, Mapping, Madidir

\begin{abstract}
Abstrak: Tujuan penelitian ini mengetahui persebaran sampah plastik di sepanjang pesisir madidir kota bitung. Jenis penelitian adalah deskriptif kuantitatif dengan menggunakan pendekatan survei yang analisis data secara spasial. Metode pengambilan sampah dilakukan dengan 2 cara, yaitu: cara pertama, pemasangan titik pada 4 lokasi tempat, yakni di madidir weru, madidir ure, madidir unet, dan madidir induk yang mengikuti garis pesisir pantai madidir. Cara kedua, ketika pemasangan titik berlangsung di 4 lokasi tempat dilakukan juga perhitungan, pengukuran, dan penimbangan secara langsung di pesisir pantai madidir. Berdasarkan hasil penelitian, sampah plastik yang diperoleh mulai dari botol minuman mineral, sedotan, gelas aqua, dll. Pada 4 titik lokasi, diketahui jumlah sampah plastik di madidir weru adalah 221 per buah, madidir unet berjumlah 172 per buah, madidir induk berjumlah 141 per buah, dan madidir ure berjumlah 71 per buah. Sedangkan jumlah total sampah plastik di sepanjang pesisir madidir kota bitung adalah 605 per buah. Hasil identifikasi sebaran sampah plastik di sepanjang pesisir madidir kota bitung tersebut, dapat diketahui berkontribusi terhadap pencemaran laut.
\end{abstract}

Kata Kunci: Sebaran, Sampah Plastik, Pemetaan, Madidir

\section{PENDAHULUAN}

Sampah merupakan segala bentuk limbah yang ditimbulkan dari kegiatan manusia maupun binatang yang biasanya berbentuk padat dan secara umum sudah dibuang, tidak bermanfaat dan tidak dibutuhkan lagi. Sedangkan sampah plastik merupakan bahan anorganik buatan yang tersusun dari bahan-bahan kimia yang cukup berbahaya bagi lingkungan, limbah dari pada plastik sangat sulit untuk diuraikan secara alami, oleh karena itu menggunakan bahan plastik dapat dikatakan tidak bersahabat ataupun konservatif bagi lingkungan apabila di gunakan tapa digunakan batasan tertentu.
Sampah pemukiman yang dibuang secara sembarangan dapat berakhir di laut, hal ini dikarenakan sampah akan terbawa oleh aliran hujan yang kemudian masuk ke sungai dan akan terbawa ke laut. Peningkatan sampah laut di wilayah pesisir, umumnya disebabkan oleh aktifitas antropogenik (Jambeck, et al., 2015).

Disamping itu, adapula sampah plastik dihasilkan dari bidang industri. Plastik menjadi salah satu bahan baku yang sering digunakan dalam kegiatan industri, yang pengelolaannya tidak semua digunakan. Jika tidak adanya tanggung jawab terhadap sisa bahan baku, maka pada akhirnya plastik 